\title{
Ekspektasi Mengenai Garis Lurus
}

\author{
Aulia Ibrahim Yeru \\ Program Studi Seni Rupa Intermedia, Fakultas Industri Kreatif, \\ Universitas Telkom
}

\begin{abstract}
The author's work in this project takes inspiration from many production processes that occur in space consumption. This author's work is focused its idea on the question whether the form that become cornerstone for designing cities or spaces has impact that could be felt directly by its inhabitants.

The context for this work is Southern Square (Alun-Alun Kidul), Yogyakarta. For author himself, Yogyakarta become appaling because its design, as a whole, based on the symettrical line which extends from Merapi Mountain to Indian Ocean. This is marked by the presence of Merapi Monument, located at the intersection of Jalan Sudirman and Jalan Margo Utomo. That symmetry axis symbolizes the philosophy or belief system of the Sultanate of Yogyakarta. The question that author try to raise is whether this symmetrical has direct impact physically and psychologically?

Borrowing the traditional game called masangin that practiced everyday in Southern Square as artmaking method, author intend to test the presence of symmetrical both physically and psychologically in several places, those are Southern Square, Gasibu Bandung, and in footpath around Institut Teknologi Bandung buidings. With eyes blindfolded, author tried to make straight line thorugh those axis of symmetries.
\end{abstract}

Keywords: walking, symmetries, public space, Alun-Alun Kidul

\section{PENDAHULUAN}

Sejak tahun 2011, penulis mencipta karya seni dengan menitik beratkan perhatian pada struktur ruang fisik. Ketertarikan tersebut dilatari oleh ketertarikan penulis pada potensi mendasar dari sebuah pencerapan atas ruang, yakni keberadaan dari penghuni itu sendiri. Kendati usaha untuk mengonstruksi ruang pada gilirannya mengatur pula bagaimana orang-orang berinteraksi di dalamnya, namun penghuni bukanlah subjek pasif yang begitu saja mengikuti konstruksi yang berada di sekitarnya. Selalu ada negosiasi di antara ruang dengan penghuninya. Namun sesungguhnya apa itu "ruang"? Sebagai entitas matematis, ruang dipahami secara kartesian sebagai satuan trimatra yang terdiri dari sumbu $x, y, z$. Namun sebagai entitas psikologis, ruang dilihat sebagai ranah terjadinya pertemuan, percampuran, bahkan pertempuran beragam kepentingan dan keinginan manusia (Hutama, 2005:318). 
Dari pengertian dasar mengenai ruang tersebut maka pertanyaan selanjutnya ialah bagaimana ruang yang spesifik pada gilirannya menciptakan reaksi tertentu dari penghuni atau orang-orang yang berada di dalamnya. Dalam karya ini, penulis mengambil kota Yogyakarta sebagai konteksnya. Bagi penulis, Yogyakarta menjadi menarik karena pada atribut-atribut fisik kota tersebut dapat ditemukan perpaduan struktur kuasa dengan hal-hal yang cenderung mistik. Pertemuan struktur tersebut dapat ditemukan dalam keseharian.

Pertanyaan yang penulis ajukan dalam karya ini ialah, jika ruang diproduksi oleh kuasa serta kemudian mewujud dalam bentuknya sebagai ruang, apakah dampak kuasa tersebut dapat dirasakan jejaknya dalam bentuk fisik dan psikis pada orangorang yang berada di dalamnya. Melalui keleluasaan untuk bereksperimen dan berspekulasi dalam karya seni, penulis melakukan aksi menggunakan tubuh penulis sendiri di dalam ruang kota, dalam hal ini kaitannya dengan Alun-Alun Kidul Yogyakarta.

\section{Gagasan Karya (Landasan Teori dan Konsep Umum)}

Secara umum, gagasan berkarya penulis bertumpu pada bentukbentuk eksperimen dan spekulasi bagaimana ruang mempengaruhi fisik penghuninya. Khususnya dalam karya ini, penulis mencoba mempertanyakan apakah ada hubungan yang terasa langsung antara tubuh dan ruang? Bagaimana wacana bahwa keduanya merupakan entitas yang tidak bisa dipisahkan? Dari pertanyaan tersebut, penulis mengambil contoh simetri sebagai pusat perhatian dari karya. Pertanyaan pun kemudian meruncing pada persoalan apakah simetri yang menjadi gagasan dasar dalam penciptaan ruang mempunyai dampak langsung secara menubuh?

Dengan memainkan permainan tradisional Masangin yang gagasan dasarnya mempunyai hubungan erat dengan perancangan kota Yogyakarta, penulis menguji apakah sistem simetri yang digunakan mempunyai dampak psikologis yang dirasakan langsung secara spontan oleh penghuninya. Pada paparan di bawah, penulis akan menjabarkan secara ringkas praktek berjalan di dalam perkembangan seni rupa, serta hubungan konsep permainan Masangin dengan kota Yogyakarta itu sendiri.

\section{Berjalan sebagai Pengalaman Estetik}

Pada karya ini, penulis menggunakan kegiatan berjalan kaki sebagai metode berkarya. Kegiatan berjalan pada dasarnya ialah kegiatan biasa yang secara alami dimiliki manusia sebagai primata yang dapat berdiri tegak. Namun berjalan sebagai sesuatu yang mempunyai makna simbolik dapat ditelusuri dari ritual-ritual yang ter 
sebar pada beberapa kepercayaan kuno dan agama-agama tertentu. Baru pada awal abad 20, berjalan mulai dilirik oleh para penggiat Dada sebagai salah satu alternatif dalam praktek berkesenian.

\section{Perkembangan Praktek Berjalan dari Dada sampai dengan Situationist International}

Sebetulnya tidak diketahui apakah ketika para penggiat Dada mulai bereksperimen dengan kegiatan berjalan mereka mengambil inspirasi dari tradisi berjalan yang penulis sebutkan di atas tadi. Yang paling jelas ialah pada kurun waktu periode tersebut berkembang wacana mengenai representasi dari gerak. Bermula dari kecenderungan Futuris yang menampilkan gerak dalam objek trimatra, para pegiat Dada berupaya mendorong agar ihwal tersebut tidak berhenti sebagai objek yang dipamerkan di ruang seni yang netral.

Lebih jauh, mereka secara langsung berupaya menembus tataran aksi dan ruang-ruang terbuka di perkotaan. Mengambil gagasan Charles Baudelaire mengenai tokoh rekaan yang disebut sebagai "le flâneur" atau pelancong, tataran aksi ini dilakukan dengan melakukan secara sengaja berjalan kaki seraya menyesatkan diri untuk kemudian berhenti di tempattempat tak terduga yang terkadang tidak jelas asal muasalnya dan entah mengapa pula tempat tersebut masih berdiri. Upaya ini juga dapat dibaca sebagai cara para penggiat Dada

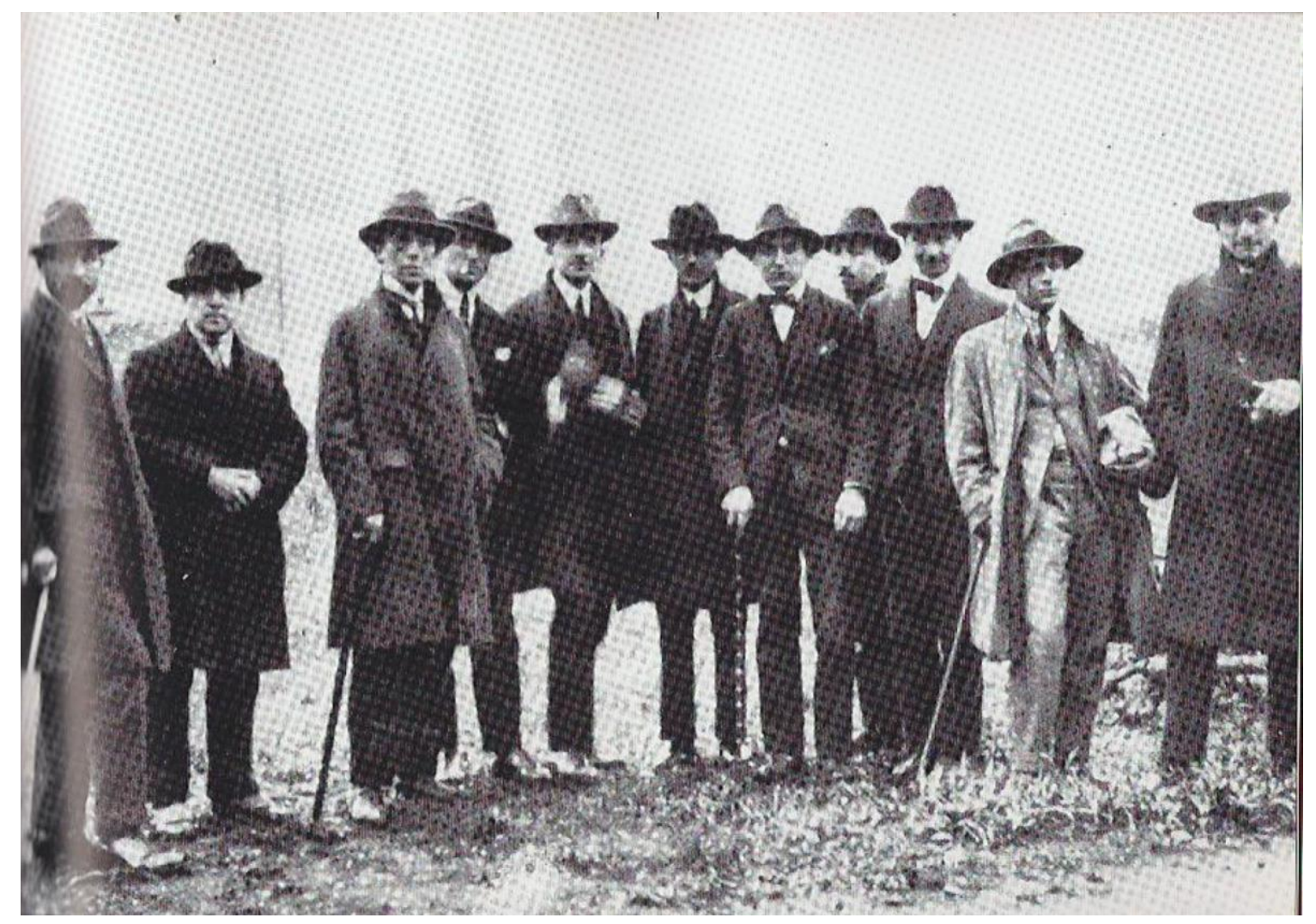

Gambar 1. "Kunjungan" para perupa Dada ke Saint-Julien-le-Pauvre, Paris. (sumber gambar: Caseri, 2009:77) 
untuk mengkritisi rancangan kota yang menurut mereka terlalu mengacu pada selera kaum menengah ke atas, seperti kelas elit dan borjuis. (Careri, 2009:72-86).

Praktek yang sebetulnya menerapkan prinsip Freud mengenai adanya "aspek ketidaksadaran" dalam rancang ruang kota ini kemudian dikembangkan lebih lanjut oleh para perupa Surealis. Bermula dari keinginan untuk mendorong perluasan dari praktek "tersesat" ala Dada, para penggiat Dada yang berdiam di Paris (mereka menamakan diri sebagai Paris Dada) mengembangkan praktek "menulis secara nirkendali di ruang terbuka" yang menurut mereka mampu menyingkap sebuah "wilayah ketidaksadaran" dari suatu ruang atau kota sebagai wilayah yang justru menghindar dari perencanaan kota yang terstruktur. Dengan ini mereka membawa praktek yang sebelumnya dilakukan oleh para penggiat Dada menjadi "lebih positif". Cara ini pula dianggap jitu dalam mewakili wilayah yang tidak dapat diterjemahkan secara representasi konvensional.

Tak lama kemudian, muncul kelompok lain yakni para penggiat Situasionist International (SI). Para penggiat dari kelompok tersebut menolak prinsip romantik yang diusung para perupa Surealis seraya berupaya mengembalikan agenda para perupa Dada dan mengarahkannya untuk menolak keelitan dari dunia seni dan kesusasteraan saat itu. Cara-caranya ialah dengan mengadakan adanya seni tanpa kultus individu seniman serta mengupayakan kerja artistik secara kolektif dan revolusioner.

Para penggiat SI lantas membuat semacam metode berjalan yang disebut sebagai dérive yang sebetulnya ialah pengembangan dari metode menggambar dan menulis sambil berjalan yang dipraktekkan sebelumnya perupa-perupa Surealis dan Dada. Perbedaannya mereka tidak mencari kenyataan yang liyan atau "zona ketidaksadaran" yang tersembunyi di sudut kota, melainkan secara penuh mengalami kota itu sendiri, dengan melihat ruang selayaknya medan perang-tempat terjadinya perebutan berbagai kepentingan. Menurut mereka, perwujudan dari perebutan kuasa tersebut tidak hanya melalui aparatur yang terlihat seperti polisi atau rambu lalu lintas, bahkan sebetulnya dapat dirasakan dalam pengaturan bentuk geometri dasar yang akan digunakan dalam rancang kota (Vaneigem dalam Grey, 26:1998).

Pada peta Gambar 2, Debord menampilkan kota Paris yang "ditelanjangi" melalui metode dérive. Dengan metode ini, peta tidak lagi menunjukkan letak geografi secara matematis, melainkan lebih menunjukkan pada momen-momen subjektif yang dialami pejalan kaki (dalam hal ini, Debord sendiri) ketika mengalami kota Paris. Dengan cara demikian, dérive dapat dimengerti sebagai upaya memahami dampak psikologis dari kehidupan urban pada 
individu penghuni kota. Mereka menyebut apa yang mereka lakukan ialah upaya untuk "menelanjangi kota". Selain itu, dalam praktek tersebut terdapat pula usaha untuk menciptakan kebiasaan baru, yaitu dengan sengaja "membuang waktu" untuk menciptakan waktu luang yang lebih manusiawi, semisal dengan digunakan untuk bermain dengan ruang (Careri, 2009:108). kemunculan beberapa genre yang cukup menonjol pada paruh awal perkembangan seni rupa kontemporer, yakni perkembangan Land Art dan Minimalisme.

Salah satu argumen penting metode ini ialah bahwasannya praktek ini dianggap efektif untuk menghadirkan pengalaman secara langsung.

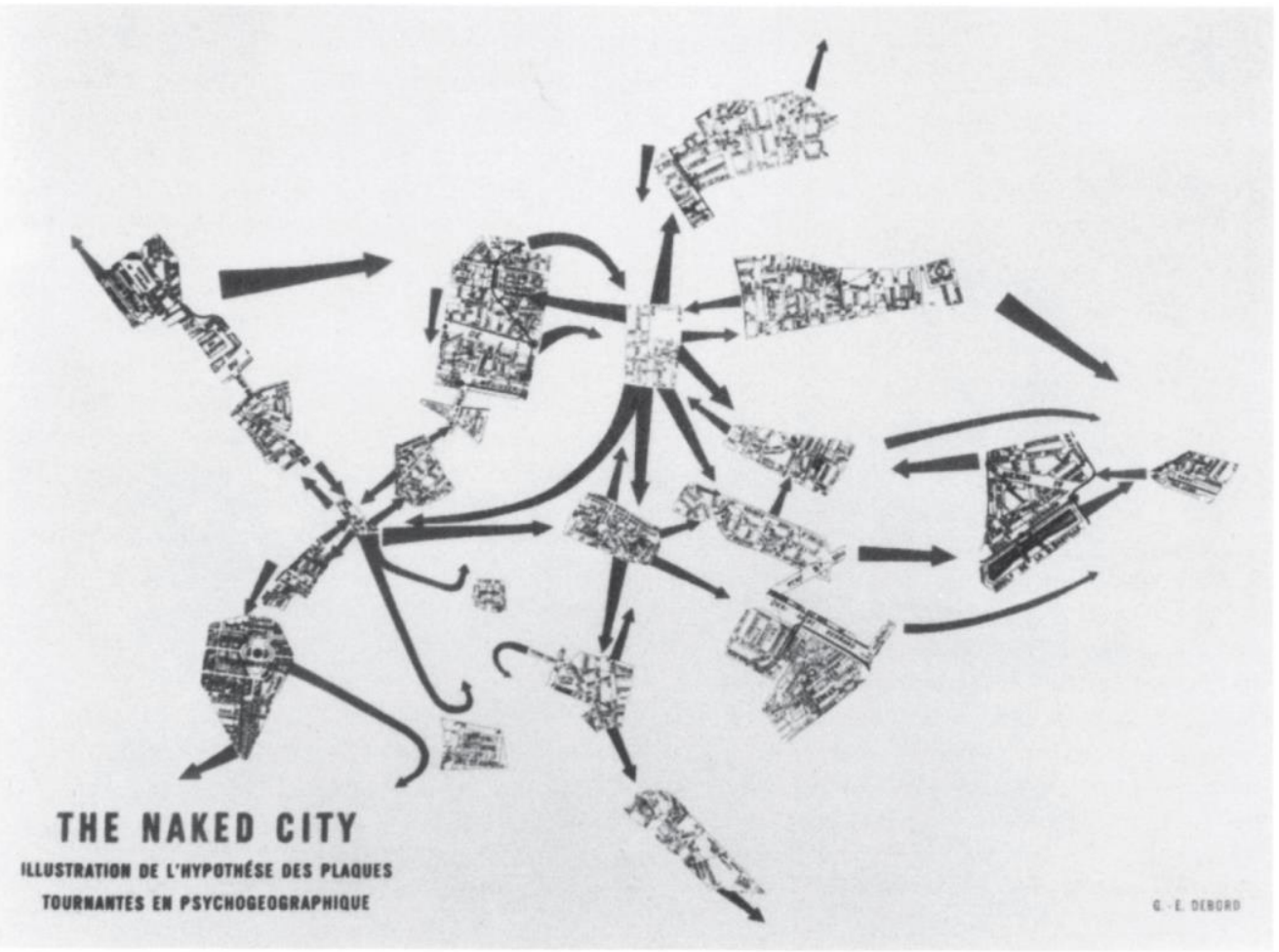

Gambar 2. Guy Debord, The Naked City. (sumber:http://www.jstor.org/stable/778967, diambil pada tanggal 20 Maret 2016Pauvre, Paris. (sumber gambar: Caseri, 2009:77)

\section{Berjalan dalam Perkembangan Dunia Seni Rupa Kontemporer}

Praktek berjalan kaki kemudian menjadi titik yang penting di dalam perkembangan seni rupa. Dimulai dari praktek berjalan kaki yang dilakukan oleh Tony Smith sepanjang jalan tol di New Jersey, praktek ini ditengarai melempangkan jalan untuk praktek ini banyak dipraktekkan oleh para sastrawan, seperti Tristan Tzara atau André Breton, praktek berjalan menjadi bagian yang penting di dalam perkembangan seni rupa saat itu, khususnya seni patung. Praktek berjalan tersebut membuat seniman saat itu kembali melihat lanskap sebagai titik penting di dalam berkarya, khususnya pada Land Art. 
Dalam genre tersebut pengerjaan patung tidak lagi membuat objek di dalam ruang, namun juga ikut mengadakan perubahan fisik pada kawasan tertentu. Kemudian, muncul seniman yang menggunakan praktek berjalan secara harfiah sebagai gagasan berkaryanya, semisal Richard Long dan Hamish Fulton. Bertolak dari wacana mengenai kedudukan patung di lanskap yang dikembangkan para perupa Land Art, mereka memilih untuk menggunakan tubuhnya sendiri untuk berjalan dan membuat jejak ketimbang secara massif mengolah lanskap.

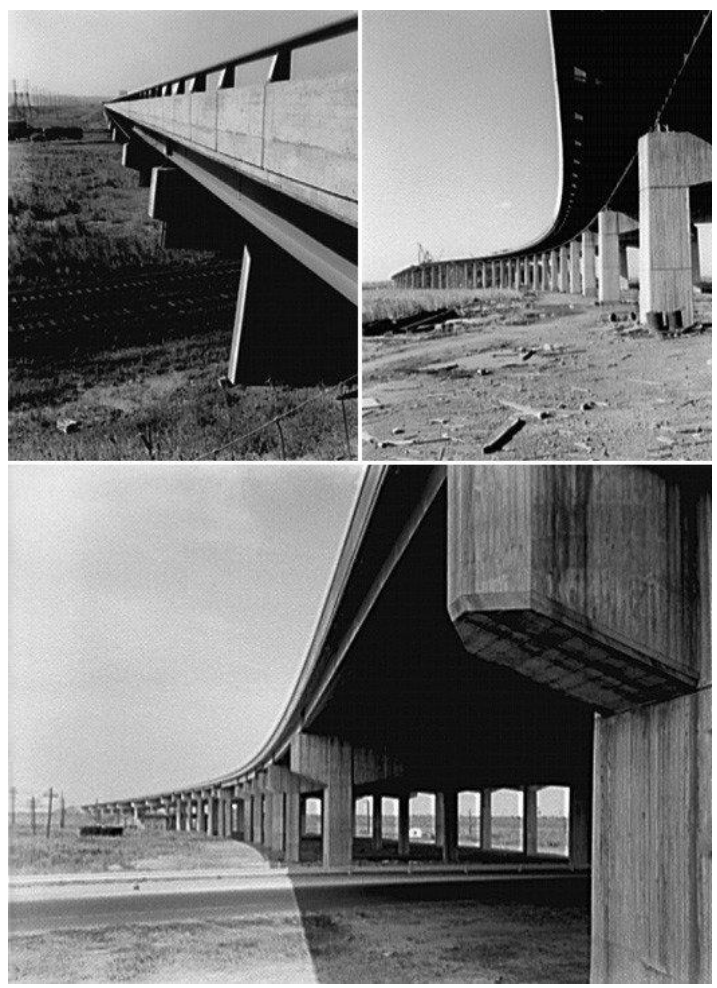

Gambar 3. Jalan Tol New York, tempat pematung Tony Smith melancarkan aksi berjalannya (sumber:https://placesjournal.org / article / thehighway-not-taken tony - smith - and-the-suburbansublime/, diambil pada 13 Juni 2016)
Menyisakan hanya foto dari jejaknya dan jejak yang akan hilang dengan waktu, yang tersisa dari jejak Long ialah ketiadaan itu sendiri. Bagi Long, Land Art terlalu besar yang tidak ada bedanya dengan monumen permanen. Ia lebih cenderung lebih ingin untuk mengadakan ziarah pada alam ketimbang mengubah bentuk dari alam itu sendiri. Dengan berjalan kaki, ia menggunakan tubuhnya sendiri sebagai alat untuk mengukur ruang dan waktu.

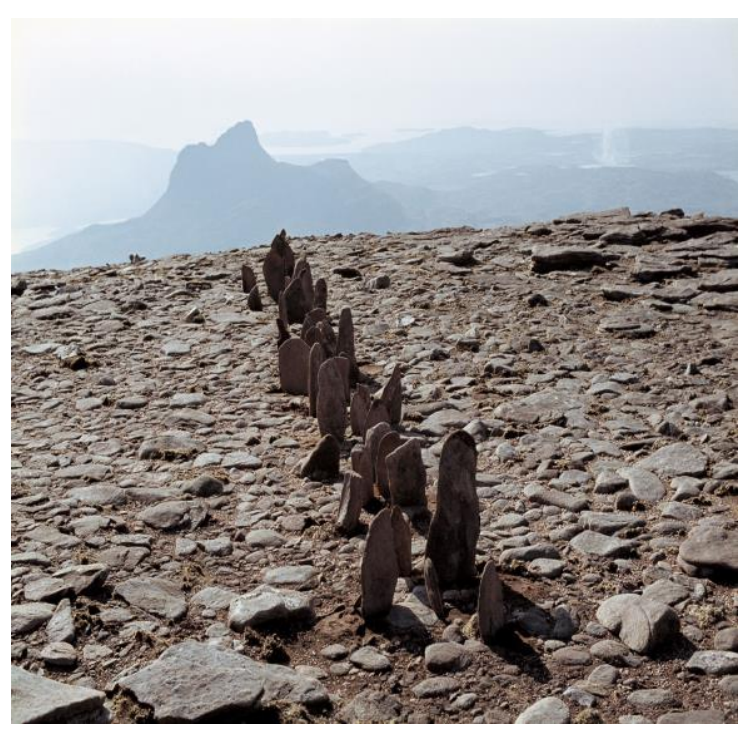

Gambar 4. Richard Long, A Line in Scotland, 1981 (sumber gambar :http://www.richardlong.org/Sc ulptures/2011sculpictures/scotli ne.html, diambil pada 20 Maret 2016)

Lebih lanjut, metode ini kemudian menjadi salah satu gestur yang cukup umum dilakukan apalagi jika menyangkut seni performans. Tercatat seniman tersohor seperti Bruce Nauman atau Marina Abramovic menggunakan praktek berjalan sebagai salah satu pilihan metodenya. 


\section{Tradisi Masangin dan Konsep Ruang Alun-Alun Yogyakarta}

Bagi penulis, tradisi pemainan menggambarkan hubungan tradisi yang mewujud di dalam ruang. Aturan permainan ini cukup sederhana, pengunjung Alun-Alun Kidul Yogyakarta ditantang untuk berjalan lurus melintasi dua pohon beringin yang terletak di tengah alunalun dengan mata yang terpejam atau ditutup dengan sehelai kain. Konon, hanya orang yang bersih hatinya yang dapat melewati kedua pohon tersebut. Tidak hanya itu, orang yang dapat melewati dua pohon beringin tersebut dikatakan akan mudah terkabul harapannya. Lebih lanjut, menurut mitos yang beredar di masyarakat, masangin mulanya digunakan untuk melatih mata batin dari para prajurit Keraton Yogyakarta.
Seiring pergeseran orientasi penggunaan Alun-Alun Kidul, tradisi masangin berangsung beralih menjadi permainan rekreasional bagi masyarakat luas yang bertandang ke tempat tersebut. Yang menarik bagi penulis ialah kehadiran "garis lurus"yang hadir di dalam permainan ini. Pasalnya, konsep ini juga menjadi konsep dasar desain kota yang secara keseluruhan membentuk simetris yang membentangkan garis lurus mulai Gunung Merapi sampai Laut Selatan. Hal ini ditandai oleh adanya Tugu Merapi yang terletak di perempatan Jalan Jenderal Sudirman dan Jalan Margo Utomo. Tidak pelak, sumbu simetri tersebut menyimbolkan falsafah atau sistem kepercayaan dari Kesultanan Yogyakarta itu sendiri, apalagi dengan menghubungkannya dengan Gunung Merapi dengan Laut Selatan.

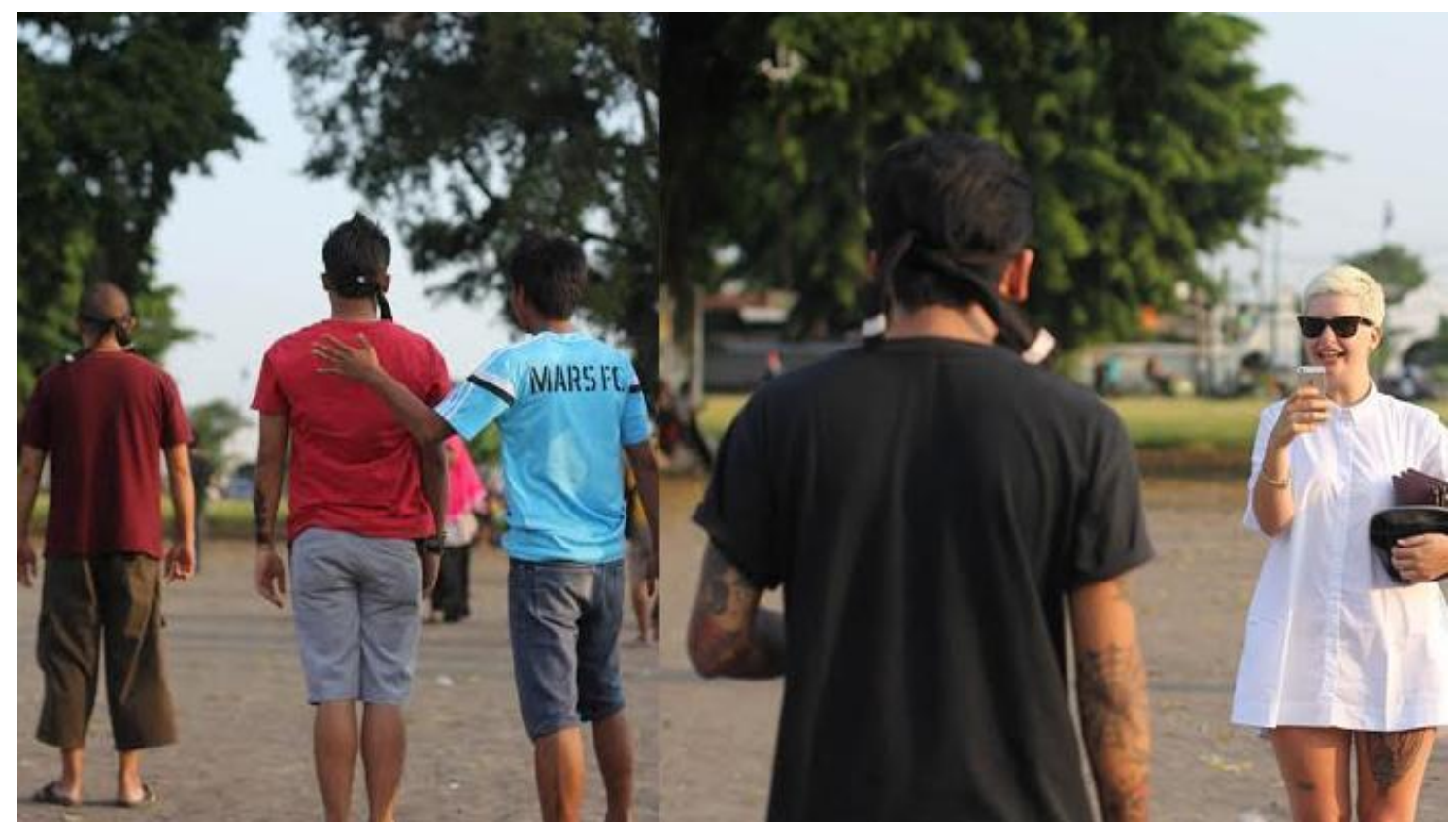

Gambar 5. Praktek Tradisi Masangin di Yogyakarta (sumber gambar: http://www.tribunnews.com/travel/2015/05/15/masangin-tradisi-permainandi-alun-alun-kidul-yogyakarta-kelihatannya-gampang-nyatanya-susah, diambil pada tanggal 30 Maret 2016) 
Kedua lokasi tersebut menempati arti yang penting dalam sistem kepercayaan yang dianut Kesultanan Yogyakarta yang memadukan ajaran Islam dengan sistem kosmik Hindu Jawa.

Pengkutuban antara Utara dan Selatan kemudian mewarnai nyaris keseluruhan sistem ruang berikut pula sistem aktivitasnya, contohnya pada aktivitas pada alun-alun Utara diselenggarakan upacara-upacara penting, semisal upacara Grebeg atau ibadah shalat Idul Fitri. Sementara alun-alun Selatan lebih sering digunakan sebagai tempat latihan prajurit, yang belakangan berfungsi sebagai ruang publik, dimana masyarakat dapat leluasa berkumpul.

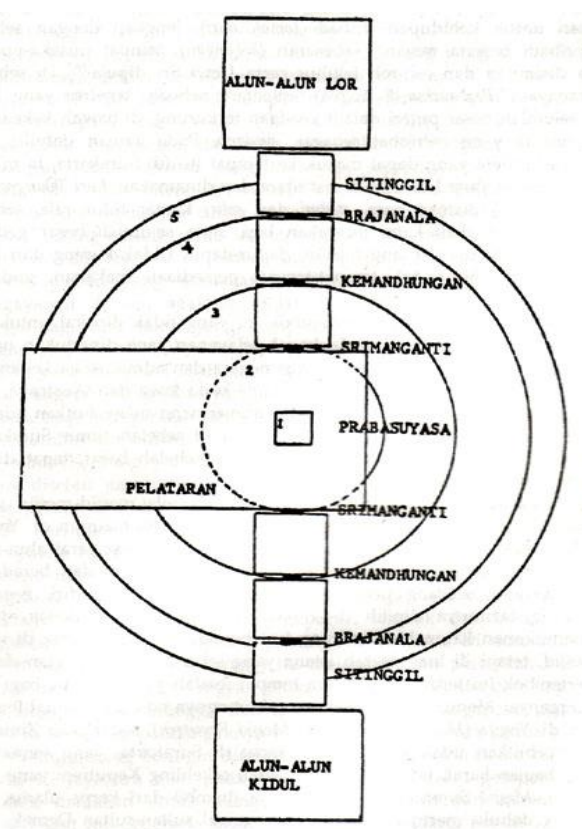

Gambar 6. Istana Jawa sebagai Imago Mundi (sumber gambar: http://space.kunci.or.id/semuabertemu-di-alun-alun-yogyakotasebagai-imajinasi-bersamaoleh-ferdiansyah-thajib, diambil pada 3 Maret 2016)
Lebih lanjut, alun-alun Utara dipandang sebagai muka atau akses utama, sedangkan alun-alun Selatan dianggap sebagai halaman belakang. Pada pemahaman simbolis, Utara dipandang "sakral", sedangkan Selatan sering dilhat sebagai "yang profan". Alun-alun Utara secara simbolik dihubungkan dengan tugu Yogyakarta yang berada di Malioboro, yang jika ditarik garis lurus akan berhubungan dengan Gunung Merapi. Pada gilirannya, pada alunalun Utara dirasakan pula perlakuan Sultan untuk menjaga simbol-simbol di dalamnya termasuk pohon beringin kembar yang ada pada alun-alun Utara. Sedangkan pada alun-alun Selatan intensitas serupa jarang ditemui. Misalnya, pada paruh dekade 1960'an, Partai Komunis Indonesia pernah membangun Taman Lalu Lintas di alun-alun Selatan (Thaib, 2010).

Berselang waktu kemudian, AlunAlun Utara berangsur jarang digunakan karena kegiatannya yang terbatas, sementara Alun-Alun Selatan seperti kebanjiran masyarakat yang hendak berpelesir. Pada tempat yang disebutkan terakhir inilah, tradisi masangin yang semula dipraktekan oleh para prajurit kini secara bebas dicoba oleh khalayak ramai.

\section{Tinjauan Karya}

Karena keterkaitan permainan masangin dengan konsep garis lurus tersebut, penulis mengadakan semacam "pengujian" dampak psikis dari garis lurus tersebut. Dalam 
pemahaman penulis, tradisi ini juga menarik karena menempatkan tubuh sebagai subjek. Seperti dalil Richard Long, dalam permainan ini tubuh menjadi alat untuk mendeteksi ruang dan waktu.

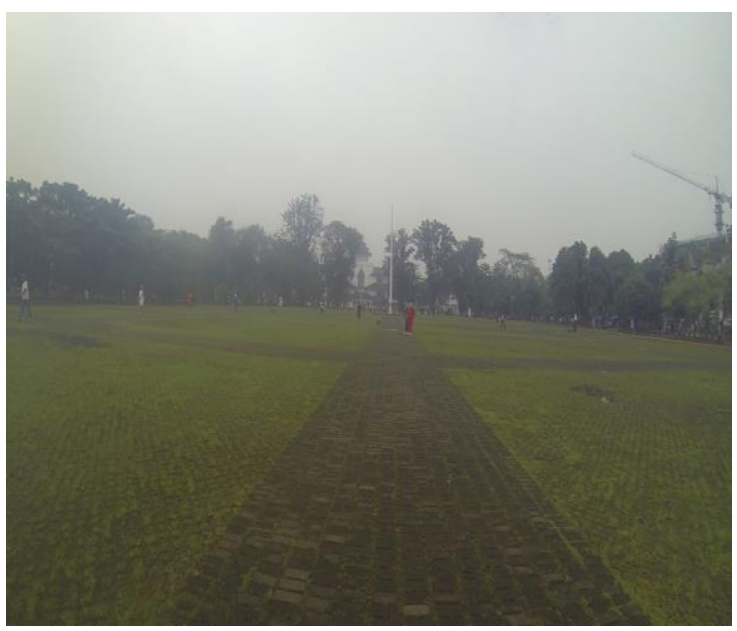

Gambar 7. Aksi penulis direkam menggunakan kamera GoPro yang ditempelkan pada tubuh penulis (dokumentasi penulis, 2015)

Sebetulnya, tidak hanya menguji apa yang berada di dalam tradisi, pertanyaan penulis kemudian merangsek pada hubungan simetri pada ruang dan dampaknya pada tubuh secara langsung. Jika pada Richard Long atau Hamish Fulton karyanya ditempatkan sebagai ziarah kembali pada ruang dan ditempatkan sebagai penghargaan terhadap sistem pada ruang atau alam sekitar, maka karya penulis ini lebih mengarah pada pertanyaan: apakah bentuk sumbu simetris tersebut mempunyai dampak yang dirasakan secara langsung? Permainan masangin, menurut penulis, dengan segala atributnya cukup lengkap untuk menghela persoalan simetri tersebut.
Menutup mata seraya berusaha berjalan lurus, bagi penulis, merupakan gestur yang efektif untuk menghela persoalan bagaimana tubuh berinteraksi dengan ruang. Harus diakui pula bahwa mata merupakan organ yang dominan dalam proses pencerapan. Bahkan tercatat bahwa proses penglihatan sendiri menghabiskan sekurangnya 50\% dari kerja otak (Politzer, 2016).

Karena fokusnya adalah menguji dampak psikis dari perancangan kota yang serba simetris tersebut, penulis mengujicobakan permainan tersebutdengan penulis sebagai pemainnya- di beberapa tempat. Permainan masangin oleh penulis ditempatkan sebagai metode untuk menguji hubungan simetri yang menjadi basis perancangan ruang dengan dampak yang dirasakan oleh tubuh itu sendiri. Yang pertama ialah di tempat dimana permainan semula dimainkan yakni di Alun-Alun Kidul Yogyakarta. Selain itu, penulis melakukan permainan ini di Kota Bandung. Di kota Bandung, penulis sengaja melakukan permainan tersebut di tempat yang juga mengambil sumbu garis lurus terhadap gunung. Jika mengambil konteks Bandung maka gunung yang dimaksud ialah Gunung Tangkuban Perahu. Beberapa bangunan di Bandung secara sengaja menempatkan Gunung Tangkuban Perahu sebagai sumbu. Tempattempat tersebut ialah Lapangan Gasibu Bandung dan Kampus Institut Teknologi Bandung. 

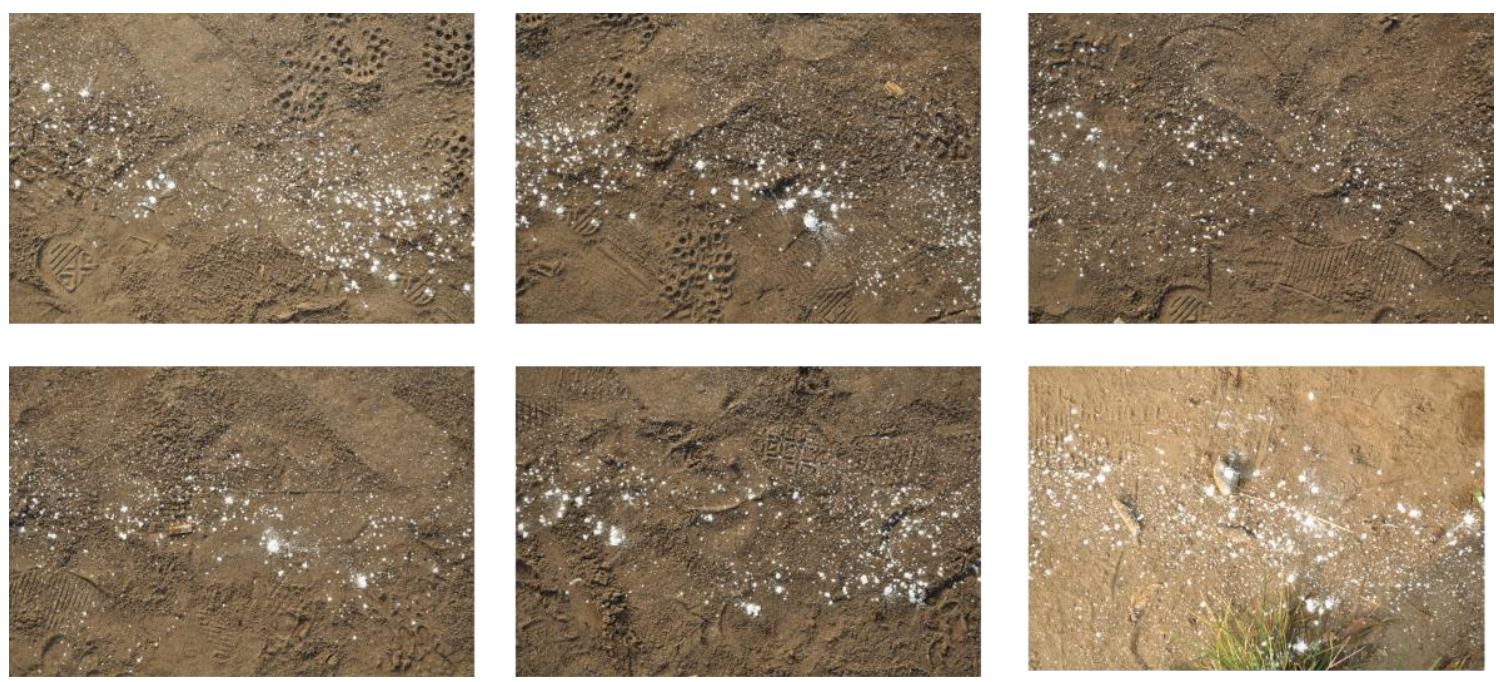

Gambar 8. Jejak dari aksi penulis (dokumentasi penulis, 2015)

Sambil berjalan dengan mata terpejam, penulis menggenggam tepung yang dengan seiring penulis berjalan tepung tersebut kemudian jatuh bertaburan. Selain itu, penulis menempelkan dua buah kamera video di badan penulis. Langkah ini penulis lakukan agar penulis dapat merekam jejak baik dari tepung yang ditaburkan juga melalui rekaman video. Hasil dokumentasi baik foto maupun video kemudian penulis ajukan sebagai karya di ruang pamer.

Ketika melakukan aksi berjalan, minus fakta bahwa penulis menggenggam tepung dan juga menggunakan perangkat kamera, tidak ada yang berbeda secara gestur dan ekspektasi dengan seseorang yang memainkan permainan tersebut. Ketika memejamkan mata dan berjalan, penulis hanya berkonsentrasi untuk membuat jalur lurus. Akan tetapi dari seluruh tempat yang penulis jelajahi, tidak satupun penulis berhasil membuat garis lurus, adapun garis yang terbuat malah melingkar. Di sini, penulis justru melihat adanya kesamaan bukan pada hubungan tubuh dan ruang, akan tetapi kondisi tubuh jika dibiarkan berjalan tanpa dilengkapi indera penglihatan.

Di dalam ruang pamer, foto-foto tersebut ditampilkan secara berurutan. Tidak semua foto ditampilkan. Pertimbangan dari keputusan tersebut tidak hanya karena kepentingan artistik namun juga menimbang bahwa karya ini ditampilkan dalam pameran bersama. Format tersebut menuntut penulis untuk mengakomodir tampilan karya dari seniman yang lain.

Pada akhirnya, penulis memilih untuk menampilkan dokumentasi fotografi dari aksi penulis yang dilakukan di Alun-Alun Kidul. Sedangkan untuk dokumentasi video, penulis menmpilkan dua layar televisi yang menampilkan dua video dari angle atau sudut pandang yang berbeda. 


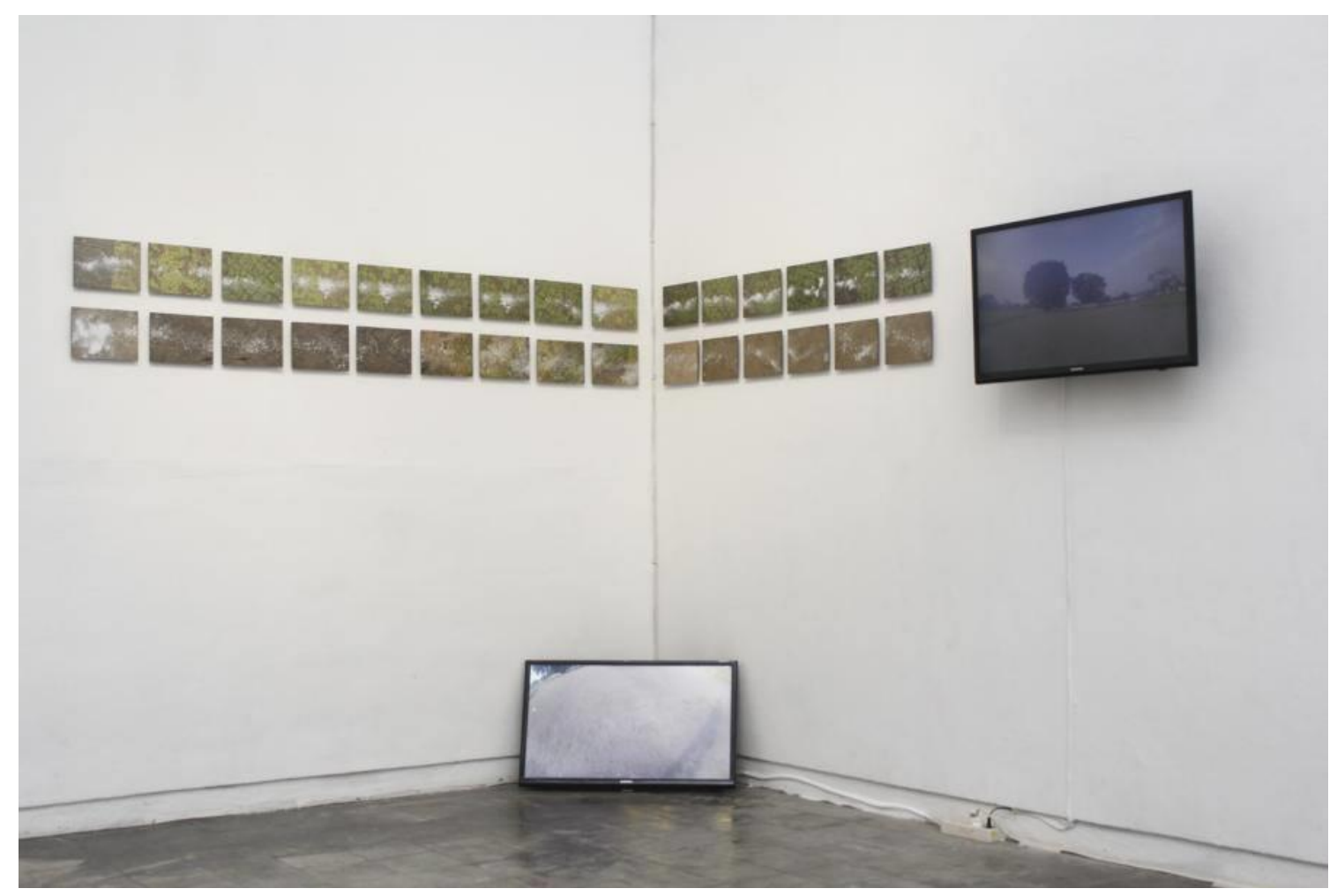

Gambar 9. Ekspektasi Mengenai Garis Lurus, dokumentasi performans (foto dan video), 2015 (dokumentasi milik penulis)

\section{KESIMPULAN}

Karya penulis pada dasarnya menguji mitos dengan cara menjalankan mitos tersebut di beberapa titik yang mempunyai kesamaan strategi ruang, yakni mengambil garis simetri terhadap kawasan tertentu. Mitos yang diuji penulis ialah mengenai tradisi Masangin yang populer dipraktekkan di Alun-Alun Kidul Yogyakarta. Dalam percobaan tidak sekalipun penulis berhasil berjalan lurus. Di semua tempat percobaan, penulis malah berjalan melingkar. Tentu penulis tidak bermaksud untuk menetapkan keberhasilan atau tidak.
Melalui karya penulis, dapat disimak bahwa sistem simetri yang penulis uji di ruang memang tidak dapat dirasakan secara langsung oleh tubuh, apalagi dengan mata tertutup. Hal ini menjadi penting karena salah satu tujuan dasar permainan masangin ialah untuk dapat berjalan lurus sepanjang 20 meter dengan mata terpejam. Bahwa yang dapat berjalan lurus ialah orang-orang yang hatinya bersih, apakah faktornya ada pada batin penulis? Hematnya saja, barangkali sistem simetri tersebut pada lain kesempatan bisa ditelusuri dengan cara yang berbeda: dengan mata yang terbuka melihat fenomena 
perkembangan ruang disekitarnya, apalagi jika menyangkut pengalaman secara holistik. Dari sini, penulis lebih memanfaatkan seni sebagai sarana menguji suatu gagasan tertentu, kendati demikian penulis harus akui bahwa pengujian ini sifatnya amat subjektif dan spekulatif.

\section{DAFTAR PUSTAKA}

Braembussche, A.

2009 Thinking Art, Springer + Business Media B.V, Amsterdam

Careri, Fransesco

2009 Walkscape: Walking as an Aesthetic Practice, Editorial Gustavo Gili SL, Barcelona

Gablik, Suzi

1998 The Nature of Beauty in Contemporary Art, New Renaissance Magazine Vol.8, No.1, London

Gray, Cristopher, ed. 1998 Leaving the 20th Century: The
Incomplete Work of the Situationist International, Rebel Pub., London

Hutama, David

2010) Ruang Publik dalam Arsitektur, Ruang Publik, Kanisius, Yogyakarta, 317-32.

Merleau-Ponty, M.

1962 Phenomenology of Perception, Routledge \& Kegan Paul Ltd, London

Stanek, Lukasz

2011 Henri Lefebore on Space: Architecture, Urban Research, and Production of Theory, University of Minnessota Press,

Minneapolis

https://placesjournal.org/article/thehighway-not-taken-tony-smithand-the-suburban-sublime/

http://space.kunci.or.id/semuabertemu-di-alun-alun-yogyakotasebagai-imajinasi-bersamaoleh-ferdiansyah-thajib http://www.jstor.org/stable/778967 